\title{
AGE-RELATED INFLUENCE OF OBESITY ON PLANTAR PRESSURE IN CHILDREN AGED 7-14
}

\author{
Yihong $\mathrm{ZHAO}^{1,2}$, Hao LIU ${ }^{1}$, Shiyang YAN ${ }^{1,2}$, Ruoyi LI, ${ }^{1,2}$ Luming YANG ${ }^{1,2^{*}}$ \\ ${ }^{1}$ National Engineering Laboratory for Clean Technology of Leather Manufacture, Chengdu, 610065, China \\ ${ }^{2}$ Key Laboratory of Leather Chemistry and Engineering (Sichuan University), Chengdu, 610065, China
}

Received: 13.12.2019 Accepted: 19.02.2020

https://doi.org/10.24264/Ifj.20.1.8

\begin{abstract}
AGE-RELATED INFLUENCE OF OBESITY ON PLANTAR PRESSURE IN CHILDREN AGED 7-14
ABSTRACT. Obesity is an important factor influencing foot geometry and function, especially for children whose musculoskeletal system are experiencing growth and maturation. The objective of this study was to examine the development of plantar pressure for the obese and normal-weight children aged 7-14 years, and the difference between the two groups in this developing duration. Totally 288 children (138 normal-weight and 150 obese) were included into the data analysis. Plantar pressure measurements were performed during barefoot walking in a self-selected speed. Contact areas, pressure-time integrals (PTI) and force-time integrals in ten plantar regions were obtained to calculate the arch index (AI) and the relative force-time integral (relFTI). Results showed that: the Al and PTI were evidently higher for obese children compared to the normal-weight group. The Al seemed to be even with age for both groups. PTI values of both groups elevated with increasing age and significance appeared from the age of 11. RelFTI values were significantly higher in lateral forefoot (M3-5) and midfoot (MF) for obese children. And the age-related changes of relFTI were different in obese children compared with normal weight ones. Obesity would obstruct normal age-related development of plantar pressure distribution.

KEY WORDS: obesity, children, footwear design
\end{abstract}

INFLUENȚA OBEZITĂȚII ÎN FUNCȚIE DE VÂRSTĂ ASUPRA PRESIUNII PLANTARE LA COPIII CU VÂRSTELE DE 7-14 ANI

REZUMAT. Obezitatea este un factor important care influențează geometria și funcția piciorului, în special pentru copiii al căror sistem musculo-scheletic crește și se maturizează. Obiectivul acestui studiu a fost de a examina dezvoltarea presiunii plantare la copiii obezi și cu greutate normală cu vârste cuprinse între 7 și 14 ani și diferența dintre cele două grupuri în această perioadă de dezvoltare. În analiza datelor au fost incluși 288 de copii (138 cu greutate normală și 150 obezi). Măsurătorile de presiune plantară au fost efectuate în timpul mersului desculț cu o viteză la alegere. S-au obținut zonele de contact, integralele presiune-timp (PTI) și integralele forță-timp în zece regiuni plantare pentru a calcula indicele plantar (AI) și integrala relativă forță-timp (relFTI). Rezultatele au arătat că Al și PTI au fost evident mai mari în cazul copiilor obezi în comparație cu grupul de copii cu greutate normală. Al părea să se echilibreze odată cu vârsta pentru ambele grupuri. Valorile PTI ale ambelor grupuri au crescut odată cu vârsta, având o semnificație crescândă de la 11 ani. Valorile RelFTI au fost semnificativ mai mari în zona laterală a antepiciorului (M3-5) și la nivelul zonei de mijloc (MF) în cazul copiilor obezi. Modificările relFTl în funcție de vârstă au fost diferite la copiii obezi în comparație cu cei cu greutate normală. Obezitatea împiedică dezvoltarea normală a distribuției presiunii plantare în funcție de vârstă.

CUVINTE CHEIE: obezitate, copii, proiectarea încălțămintei

L'INFLUENCE DE L'OBÉSITÉ LIÉE À L'ÂGE SUR LA PRESSION PLANTAIRE CHEZ LES ENFANTS DE 7 À 14 ANS

RÉSUMÉ. L'obésité est un facteur important qui influence la géométrie et la fonction du pied, en particulier pour les enfants dont le système musculo-squelettique connaît une croissance et une maturation. L'objectif de cette étude a été d'examiner le développement de la pression plantaire chez les enfants obèses et de poids normal âgés de 7 à 14 ans, et la différence entre les deux groupes dans cette durée de développement. Au total, 288 enfants (138 de poids normal et 150 obèses) ont été inclus dans l'analyse des données. Des mesures de pression plantaire ont été effectuées lors de la marche à pieds nus à une vitesse auto-sélectionnée. Les zones de contact, les intégrales pression-temps (PTI) et les intégrales force-temps dans dix régions plantaires ont été obtenues pour calculer l'indice de la voûte plantaire (Al) et l'intégrale force-temps relative (relFTI). Les résultats ont montré que l'Al et le PTI ont été évidemment plus élevés chez les enfants obèses que pour le groupe des enfants au poids normal. L'Al semblait s'équilibrer avec l'âge pour les deux groupes. Les valeurs de PTI des deux groupes ont augmenté avec l'âge et une signification est apparue dès l'âge de 11 ans. Les valeurs de relFTI ont été significativement plus élevées à l'avant-pied latéral (M3-5) et au milieu du pied (MF) pour les enfants obèses. Les changements des relFTI liés à l'âge ont été différents chez les enfants obèses par rapport à ceux de poids normal. L'obésité empêche le développement normal de la répartition de la pression plantaire selon l'âge.

MOTS CLÉS : obésité, enfants, conception de chaussures

\footnotetext{
"Correspondence to: Luming YANG, National Engineering Laboratory for Clean Technology of Leather Manufacture, Chengdu, 610065, China, ylmll1982@126.com
} 


\section{INTRODUCTION}

Obesity has been associated with orthopedic problems due to the increasing joint stress and overload on the musculoskeletal structures, especially for the children and adolescents whose musculoskeletal system are experiencing maturation [1-3]. Children obesity is commonly related to a flatter foot pattern and a lower postural stability, resulting in bad performance in some weight bearing activities and higher risks of injuries [2, 4-8]. Foot is the medium between human body and the environment (ground) [9] and therefore the excess weight, laying more burden on children's muscles and bones of lower extremities, will affect the plantar pressure distribution in some way. Studies have found larger contact areas and increased plantar pressure for the obese children while walking or running $[10,11]$. Similar difference was reported by Yan et al. [2, 12], and their data also showed an increase in the arch index of the obese children's left feet. Therefore, special shoe lasts are needed in footwear design for children with obesity.

Children's musculoskeletal system is subject to complex developmental processes of bony and muscular structures [13], making it a typical gait pattern and foot geometry as well as its special developmental changes different from the adults [14]. Researchers have studied the development of gait in normal children and adolescents, involving both the cross-sectional studies and the longitudinal investigations [13, 15-19]. It was reported that children's plantar peak pressure increased with age, and the relative maximum force in the midfoot decreased accompanied by a higher foot arch [13]. Furthermore, the area, in which the highest peak pressure appeared, turned from rearfoot to forefoot with increasing age [19]. Therefore, some reference data were exhibited for normal children's gait recognition regarding plantar pressure and foot arches [13, 16, 20-23].

While most previous cross-sectional and follow-up literature was focused on the normal children, data of gait development for obese children are lacking. According to a deep literature review, Mueller et al. [24] discussed the influence of obesity on foot loading for consecutive years, and found that obese children showed greater difference with increasing age in midfoot loading (FTI) compared to normalweight ones. Obese children would have higher incidences to become obese adults [25], and the effect of obesity on the children's gait might be long-term. Therefore, it's imperative to figure out the development of the special gait for obese children during childhood, to establish a reference database of gait pattern like that of the normal weight children. Analysis of more foot function parameters and larger age ranges need to be conducted.

The purpose of this study was two-fold: first, to investigate the influence of obesity on plantar pressure through childhood to early adolescence. Second, it aimed to investigate the age-related changes in plantar pressure of obese children ranging from 7 to 14 years. It can expectedly provide a better understanding of age-related plantar pressures in children with obesity. It was anticipated that this may enable the adaptation and improvement of materials of shoe components and structures and sizes of shoe lasts when designing footwear for children with obesity.

\section{METHODS}

\section{Participants}

This study involved 734 children, recruited from randomly selected local primary school and middle school in Yantai city, China. Children were excluded if they had any history of lower extremity injuries, gross gait abnormalities, neuromusculoskeletal condition or cardiovascular diseases. Furthermore, to avoid gender difference [26], we focused on plantar pressure in obese boys in this study. Finally 138 normal-weight (NW) and 150 obese (OB) boys aged 7 to 14 years old were screened according to the Chinese body mass Index reference norm [27]. Basic information of the participants is detailed in Table 1. Written informed consent was received from parents of all potential participants prior to the test. The study was approved by the Ethics Committee of Sichuan University. 
Table 1: Basic information of the participants

\begin{tabular}{ccccccccc}
\hline Age & & & NW & & & OB \\
& $\mathrm{N}$ & Height $/ \mathrm{cm}$ & Body mass $/ \mathrm{kg}$ & $\mathrm{BMI} /\left(\mathrm{kg} / \mathrm{m}^{2}\right)$ & $\mathrm{N}$ & Height $/ \mathrm{cm}$ & Body mass $/ \mathrm{kg}$ & $\mathrm{BMI} /\left(\mathrm{kg} / \mathrm{m}^{2}\right)$ \\
\hline 7 & 19 & $126.8 \pm 3.6$ & $24.4 \pm 2.8$ & $15.2 \pm 1.1$ & 13 & $134.5 \pm 6.2$ & $41.0 \pm 7.9$ & $22.5 \pm 2.7$ \\
8 & 46 & $130.6 \pm 4.1$ & $27.1 \pm 2.8$ & $15.8 \pm 1.2$ & 33 & $138.0 \pm 5.3$ & $44.6 \pm 7.2$ & $23.3 \pm 2.7$ \\
9 & 16 & $135.4 \pm 5.0$ & $30.4 \pm 4.1$ & $16.6 \pm 1.6$ & 21 & $142.6 \pm 5.9$ & $51.1 \pm 7.8$ & $25.0 \pm 2.4$ \\
10 & 15 & $143.0 \pm 6.5$ & $34.5 \pm 5.9$ & $16.7 \pm 1.8$ & 20 & $148.2 \pm 6.6$ & $58.0 \pm 8.7$ & $26.3 \pm 2.6$ \\
11 & 14 & $147.7 \pm 6.3$ & $39.3 \pm 5.5$ & $17.9 \pm 1.6$ & 15 & $152.4 \pm 7.3$ & $65.4 \pm 10.6$ & $28.0 \pm 2.7$ \\
12 & 15 & $155.0 \pm 7.6$ & $42.2 \pm 6.4$ & $17.5 \pm 2.1$ & 24 & $163.6 \pm 7.0$ & $75.7 \pm 8.6$ & $28.3 \pm 2.9$ \\
13 & 9 & $162.8 \pm 7.3$ & $50.4 \pm 7.9$ & $18.9 \pm 1.5$ & 14 & $169.3 \pm 8.3$ & $84.8 \pm 12.9$ & $29.4 \pm 2.6$ \\
14 & 4 & $164.9 \pm 6.5$ & $54.0 \pm 6.2$ & $19.8 \pm 1.0$ & 10 & $171.5 \pm 6.2$ & $88.8 \pm 4.2$ & $30.2 \pm 1.5$
\end{tabular}

\section{Plantar Pressure Measurements}

Plantar pressure data were collected using a Footscan ${ }^{\circledR}$ plate system (RSscan Inc., Belgium; $7.7 \mathrm{~kg} ; 1068 \mathrm{~mm} \times 418 \mathrm{~mm} \times 12 \mathrm{~mm}$; 4 sensors/ $\mathrm{cm}^{2}$ ) with a sampling rate of $250 \mathrm{~Hz}$. The plantar pressure plate was mounted in the middle of a $6-\mathrm{m}$ rigid rubber track of same height, to estimate a natural walking condition. After a familiarization with the plate and the experimental procedure, participants were asked to walk through the plates barefoot at a self-selected speed, using a "two-step" initial protocol, which confirmed two complete footprints on the plate (Figure 1). Five successful footprints of each foot were recorded.

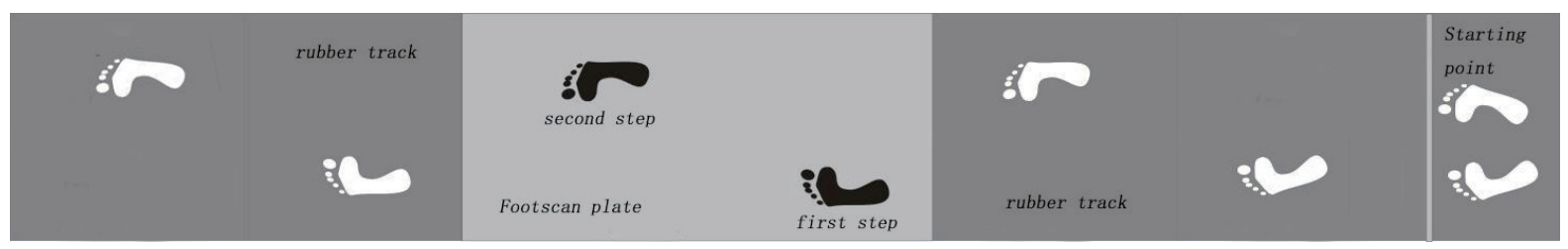

Figure 1. "Two-step" initial protocol

\section{Data Analysis}

Foot was divided into ten regions by Footscan ${ }^{\circledR}$ software and artificial adjustments according to the anatomical principal: Toe 1 (T1), Toes 2-5 (T2-5), the first to fifth metatarsal (M1, M2, M3, M4, M5), Midfoot (MF), Heel medial $(\mathrm{HM})$, Heel lateral $(\mathrm{HL})$.

Only the pressure data of the right foot were analyzed in this study [28]. Data of related parameters from three relative stable

$$
A l=\frac{C A_{\text {Midfoot }}}{C A_{\text {forefoot }}+C A_{\text {midfoot }}+C A_{\text {hindfoot }}}
$$

$$
\text { relFTI }=\frac{F T I}{\sum F T I} \times 100 \%
$$

measurements of each subject were averaged for each participant. The parameters included arch index (Al), pressure-time integral (PTI, N.s/ $\mathrm{cm}^{2}$ ) and relative force-time integral (relFTI, \%) of ten regions. A high arch would result in a small Al according to Cavanagh's definition [29], and the reIFTI (the FTI in one region divided by the FTI of all regions) would indicate the plantar pressure distribution to some extent [30]. The Al described by Cavanagh et al. [29] and the relFTI were calculated as follows:

\section{Statistical Analysis}

Normality of the data for every group was assessed using Frequencies analysis and Kolmogorov-Smirnov test, and all data were found to be normally distributed (skewness $<1$, kurtosis<1; $p>0.05$ ). Differences between $\mathrm{NW}$ and $\mathrm{OB}$ in each age stage were tested by Independent Samples T Test. One-way ANOVA test was applied to evaluate differences among 8 age stages (7-14 years old), separately for either 
body type group, with a Bonferroni correction and post-hoc test.

\section{RESULTS}

Higher Al values were found in the obese children through the ages during 7 and 14 years old. No systematic increase or decrease was observed with the increasing age in either of the two groups (Figure 2).

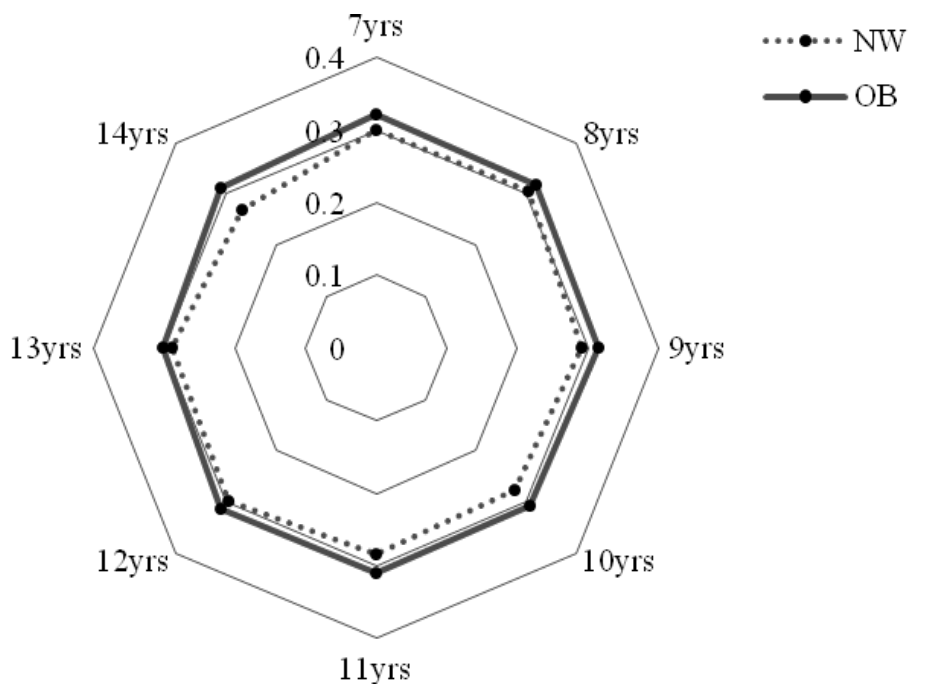

Figure 2. The Al in obese and normal-weight participants aged 7-14

Obese children showed relatively higher pressure-time integrals than their normalweight counterparts in all plantar regions (Table 2). And the significance was found in almost all the foot regions except for T1 and T2-5, in which the significances were only found in 7 year-old children.

The pressure-time integral (PTI) for both of the BMI groups showed a continuous increase with age in almost every foot region. Significances were found in forefoot, midfoot and heel areas between age groups for obese children. The PTI in normal weight children were in the same conditions, but for the midfoot $(p=0.052)$. Significantly higher PTI values were observed in most areas at the age of 12-14 compared to those at the age of 7-9.

Table 2: The pressure-time integral (PTI, N-s/ $\mathrm{cm}^{2}$ ) for the participants aged 7-14

\begin{tabular}{|c|c|c|c|c|c|c|c|c|c|c|}
\hline & & 7 & 8 & 9 & 10 & 11 & 12 & 13 & 14 & $\mathrm{p}$ \\
\hline \multirow{2}{*}{$\mathrm{T} 1$} & NW & $0.6(0.4)$ & $0.7(0.6)$ & $0.7(0.3)$ & $0.9(0.4)$ & $0.7(0.4)$ & $1.1(0.7)$ & $1.0(0.5)$ & $1.1(0.3)$ & 0.101 \\
\hline & $\mathrm{OB}$ & $1.2(0.8)$ & $1.2(0.8)$ & $1.2(0.7)$ & $1.3(0.8)$ & $1.1(0.6)$ & $1.5(0.8)$ & $1.4(0.8)$ & 2.1 (1.4) & 0.068 \\
\hline \multirow{2}{*}{ T2-5 } & NW & $0.2(0.1)$ & $0.2(0.2)$ & $0.2(0.1)$ & $0.2(0.1)$ & $0.2(0.1)$ & $0.2(0.1)$ & $0.6(0.2)$ & $0.2(0.1)$ & 0.729 \\
\hline & $\mathrm{OB}$ & $0.3(0.2)$ & $0.2(0.2)$ & $0.2(0.1)$ & $0.3(0.2)$ & $0.3(0.3)$ & $0.3(0.2)$ & $0.2(0.1)$ & $0.5(0.2)$ & 0.099 \\
\hline \multirow{2}{*}{ M1 } & NW & $0.7(0.5)$ & $0.9(0.6)$ & $1.0(0.5)$ & $1.3(0.6)$ & $1.1(0.5)$ & $1.1(0.6)$ & $1.6(0.6) 7$ & $1.9(1.0)^{78}$ & $0.000^{*}$ \\
\hline & OB & $1.5(1.1)$ & $1.6(1.1)$ & $1.6(0.7)$ & $1.5(0.6)$ & $1.5(0.8)$ & $1.7(0.8)$ & $2.4(1.2)$ & $2.4(1.3)$ & $0.022^{*}$ \\
\hline \multirow{2}{*}{ M2 } & NW & $1.4(0.8)$ & $1.8(1.1)$ & $2.2(0.9)$ & $2.7(0.8)^{7}$ & $2.6(1.3)$ & $2.7(1.3)^{7}$ & $3.8(0.9)^{7-9}$ & $3.9(1.0)^{78}$ & $0.000^{*}$ \\
\hline & $\mathrm{OB}$ & $3.2(2.2)$ & $3.2(1.4)$ & $3.5(0.9)$ & $3.6(1.0)$ & 3.7 (1.6) & $5.0(2.1)^{8}$ & $5.9(2.4)^{7-11}$ & $6.0(1.4)^{7-11}$ & $0.000^{*}$ \\
\hline \multirow{2}{*}{ M3 } & NW & $1.6(0.9)$ & $1.9(1.3)$ & $2.2(0.8)$ & $2.5(0.6)$ & $2.8(1.7)$ & $3.3(1.3)^{78}$ & $3.8(1.0)^{7-9}$ & $4.1(1.9)^{78}$ & $0.000^{*}$ \\
\hline & $\mathrm{OB}$ & 3.6 (1.9) & $3.6(1.4)$ & $4.0(1.3)$ & 4.2 (1.5) & $4.8(1.8)$ & $6.0(2.2)^{7-10}$ & $6.6(2.1)^{7-10}$ & $7.0(1.0)^{7-10}$ & $0.000^{*}$ \\
\hline \multirow{2}{*}{ M4 } & NW & $1.3(0.9)$ & $1.5(1.0)$ & $1.7(0.8)$ & $1.7(0.5)$ & $2.4(1.9)$ & $2.6(0.9)^{78}$ & $2.9(0.7)^{78}$ & $2.7(1.4)$ & $0.000^{*}$ \\
\hline & $\mathrm{OB}$ & $2.9(1.2)$ & $3.0(1.2)$ & $3.3(1.1)$ & $3.8(1.2)$ & $4.4(2.6)$ & $5.3(2.0)^{7-9}$ & $5.2(1.7)^{7-9}$ & $5.4(1.1)^{7-9}$ & $0.000^{*}$ \\
\hline \multirow{2}{*}{ M5 } & NW & $0.4(0.3)$ & $0.5(0.5)$ & $0.6(0.4)$ & $0.6(0.3)$ & $1.0(0.6)^{78}$ & $1.1(0.7)^{78}$ & $1.4(0.7)^{7-9}$ & $0.8(0.5)$ & $0.000^{*}$ \\
\hline & $\mathrm{OB}$ & $1.2(0.8)$ & $1.2(0.6)$ & $1.6(0.8)$ & $1.8(0.7)$ & $2.3(2.0)^{8}$ & $2.8(1.4)^{7-9}$ & $2.2(0.9)$ & $2.7(0.8)^{78}$ & $0.000^{*}$ \\
\hline \multirow{2}{*}{ MF } & NW & $0.4(0.3)$ & $0.5(0.3)$ & $0.5(0.3)$ & $0.5(0.3)$ & $0.5(0.4)$ & $0.6(0.4)$ & $0.9(0.4)^{78}$ & $0.4(0.2)$ & 0.052 \\
\hline & $\mathrm{OB}$ & $1.0(0.7)$ & $0.9(0.5)$ & $1.2(0.5)$ & $1.2(0.4)$ & $1.2(0.7)$ & $1.3(0.6)$ & $1.7(0.9)^{8}$ & $1.5(0.7)$ & $0.002^{*}$ \\
\hline \multirow{2}{*}{$\mathrm{HM}$} & NW & $1.5(0.9)$ & $1.7(1.0)$ & $1.7(0.7)$ & $2.1(0.7)$ & $2.0(1.1)$ & $2.1(0.7)$ & $2.6(1.1)$ & $2.7(0.8)$ & $0.028^{*}$ \\
\hline & $\mathrm{OB}$ & $2.2(1.2)$ & $2.2(1.0)$ & $3.2(1.0)$ & $2.9(0.7)$ & $2.9(1.4)$ & $3.0(1.3)$ & $4.1(1.8)^{78}$ & $3.9(1.3)^{78}$ & $0.000^{*}$ \\
\hline
\end{tabular}




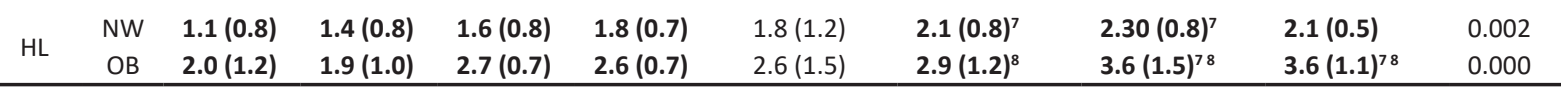

Figures in bold indicate significant difference between obese participants and the normal-weight counterparts $(p<0.05)$. ${ }^{n}$ significantly different from PTI at age of n, e.g. ${ }^{7-11}$ in $\mathrm{M} 2$ area of 13 year-old OB group indicates that significant differences for PTI were found for children with obesity between age of 13 and $7.8,9,10,11$, respectively; ${ }^{*} p<0.05$, significantly different between age groups, by One-way ANOVA test.

The relative force-time integral data were illustrated in Table 3. Higher values of the relFTI were found for the 7-14 years obese children in lateral forefoot (M3, M4 and M5) and the midfoot. Conversely, the obese cohort showed lower relFTI in the Toes (T1, T2-5), medial forefoot (M1 and $\mathrm{M} 2$ ) and the heel (HM and $\mathrm{HL}$ ). Significance of the difference nearly disappear from age of 11 .
Rare significantly regular changes were found between and within age groups in relFTI values of both obese and normal weight children. RelFTI in midfoot for normal weight participants kept decreasing with aging, but those of obese children kept a relatively even trend.

Table 3: The relative force-time integral (relFTI, \%) for the participants aged 7-14

\begin{tabular}{|c|c|c|c|c|c|c|c|c|c|c|}
\hline & & 7 & 8 & 9 & 10 & 11 & 12 & 13 & 14 & $p$ \\
\hline \multirow{2}{*}{$\mathrm{T} 1$} & $\mathrm{~N}$ & $6.7(3.5)$ & $7.3(4.6)$ & $6.7(3.3)$ & $6.9(3.1)$ & $7.0(5.6)$ & $7.9(5.2)$ & $5.8(3.2)$ & 7.5 (1.5) & 0.960 \\
\hline & 0 & $6.9(3.3)$ & $6.5(3.5)$ & $5.6(3.0)$ & $5.5(2.8)$ & $4.6(3.0)$ & $5.5(2.7)$ & $5.2(3.1)$ & $6.4(4.3)$ & 0.474 \\
\hline \multirow{2}{*}{ T2-5 } & $\mathrm{N}$ & $2.9(2.4)$ & $2.3(1.9)$ & $2.1(1.4)$ & $3.2(3.6)$ & $1.6(1.3)$ & $1.8(1.3)$ & $2.2(1.2)$ & $2.1(1.1)$ & 0.409 \\
\hline & $\mathrm{O}$ & $1.9(1.0)$ & $2.0(2.0)$ & $1.5(1.1)$ & $1.8(1.2)$ & $1.9(1.8)$ & $1.4(0.9)$ & $1.1(0.7)$ & $2.2(1.2)$ & 0.309 \\
\hline \multirow{2}{*}{ M1 } & $\mathrm{N}$ & $10.6(7.6)$ & $11.3(6.7)$ & $11.5(5.8)$ & $11.0(5.0)$ & $10.5(5.8)$ & $9.0(5.7)$ & $9.6(3.8)$ & $12.4(5.9)$ & 0.929 \\
\hline & $\mathrm{O}$ & $9.4(4.0)$ & $11.7(6.7)$ & $8.7(4.2)$ & $7.7(3.2)$ & $8.1(4.2)$ & $7.1(3.4)$ & $8.9(3.3)$ & $8.8(5.1)$ & $0.017^{*}$ \\
\hline \multirow{2}{*}{ M2 } & $\mathrm{N}$ & $12.0(5.2)$ & $12.2(6.1)$ & $14.4(6.4)$ & $13.8(5.4)$ & $14.5(4.7)$ & $12.4(5.9)$ & $12.7(2.3)$ & $14.1(1.3)$ & 0.744 \\
\hline & $\mathrm{O}$ & $12.5(4.5)$ & $13.0(4.8)$ & $10.9(2.5)$ & $11.0(2.7)$ & $12.2(4.8)$ & $13.4(5.4)$ & $12.7(3.6)$ & $12.2(2.5)$ & 0.428 \\
\hline \multirow{2}{*}{ M3 } & $\mathrm{N}$ & $11.2(3.4)$ & $10.5(4.4)$ & $11.6(4.0)$ & $11.8(4.3)$ & $12.6(4.1)$ & $13.5(2.6)$ & $12.8(3.9)$ & $13.9(3.0)$ & 0.162 \\
\hline & 0 & $13.9(4.0)$ & 13.4 (3.9) & 11.5 (3.0) & $12.2(3.6)$ & $13.3(3.3)$ & 14.7 (3.4) & $13.6(2.6)$ & $13.3(2.1)$ & 0.203 \\
\hline \multirow{2}{*}{ M4 } & $\mathrm{N}$ & $8.3(4.7)$ & $7.5(3.3)$ & $8.4(3.1)$ & $8.1(2.7)$ & $9.8(4.8)$ & $10.3(3.1)$ & $9.7(2.8)$ & $8.9(3.5)$ & 0.149 \\
\hline & 0 & $11.0(3.5)$ & $10.0(3.1)$ & $9.3(2.6)$ & $10.8(3.3)$ & $11.1(4.1)$ & $12.5(4.5)$ & $10.2(2.2)$ & $10.0(2.5)$ & 0.076 \\
\hline \multirow{2}{*}{ M5 } & $\mathrm{N}$ & $2.2(1.8)$ & $2.5(2.2)$ & $3.3(2.0)$ & $3.6(1.6)$ & $4.5(2.3)$ & $4.5(2.9)$ & $4.7(2.4)$ & $2.8(2.0)$ & $0.002^{*}$ \\
\hline & 0 & 3.9 (1.6) & $4.1(2.1)$ & $4.9(2.4)$ & $6.0(2.8)$ & $6.6(4.1)$ & $6.1(2.8)$ & $4.6(1.7)$ & $5.4(1.4)$ & $0.007^{*}$ \\
\hline \multirow[b]{2}{*}{ MF } & $N$ & $12.9(8.5)$ & $11.8(6.5)$ & $10.7(5.6)$ & $10.4(6.0)$ & $8.4(5.8)$ & $9.5(6.5)$ & $12.0(5.6)$ & $5.7(2.8)$ & 0.317 \\
\hline & 0 & $15.2(6.8)$ & $14.2(7.5)$ & $15.9(7.4)$ & $14.8(6.0)$ & $14.4(5.5)$ & $13.4(5.8)$ & $15.0(7.5)$ & $14.1(7.5)$ & 0.963 \\
\hline \multirow{2}{*}{ HM } & $\mathrm{N}$ & 20.7 (11.4) & 20.4 (9.9) & $17.7(4.7)$ & $16.8(4.7)$ & $17.4(7.0)$ & $16.3(5.8)$ & $17.3(6.1)$ & $19.0(1.2)$ & 0.536 \\
\hline & 0 & $13.8(4.0)$ & $14.3(4.0)$ & $18.4(5.2)$ & $16.8(5.2)$ & $16.1(5.8)$ & $14.2(6.2)$ & $16.2(4.1)$ & $15.49(4.8)$ & 0.063 \\
\hline \multirow{2}{*}{$\mathrm{HL}$} & $\mathrm{N}$ & $12.6(4.8)$ & $14.3(6.6)$ & $13.8(3.4)$ & $14.3(3.8)$ & $13.7(6.8)$ & $14.7(5.8)$ & $13.2(3.8)$ & $13.63(3.7)$ & 0.959 \\
\hline & $\mathrm{O}$ & $11.6(4.1)$ & $10.7(4.1)$ & $13.4(3.1)$ & $13.2(3.8)$ & $11.8(4.5)$ & $11.8(4.6)$ & $12.5(3.8)$ & $12.13(3.4)$ & 0.322 \\
\hline
\end{tabular}

Figures in bold indicate significant difference between obese participants and the normal-weight counterparts $(p<0.05)$, by Independent Samples T Test; ${ }^{*} p<0.05$, significantly different between age groups, by One-way ANOVA test.

\section{DISCUSSION}

Since BMI (obesity) and age are both important factors for children' gait and foot function $[2,4,13,15,31]$, the study purposed to examine the different development of the plantar pressure distribution (PTI, relFTI) and foot geometry (Al) between the obese and the normal weight children across their body growth and maturation (7-14 years old).

Although obese children generated a higher arch index than the normal-weight ones, no evident increasing or decreasing trends were found in the Al parameters, suggesting that the longitudinal arches have finished developing before 7 years old for both of the BMI groups. The findings are partly consistent with the results from Mueller et al. [24], who established Al data in 1-12 years old normal-weight, overweight and obese children and found that the arch indexes for the three groups decreased with age until about 7 years old. Bosch et al. [13] also gained similar Al trend for normal children in a longitudinal investigation. However, the Al values in the two studies seemed lower than those in 
the same BMI categories of this study, which may be resulted from different plantar divisions and regional differences between China and Germany. The relatively even development of arch index in the obese cohort may indicate that a "maturation" stage similar with the normalweight children would occur before the age of 7 , which meant that the influence of obesity did exist on the longitudinal arch, but it would not accumulate with age after 7 years old.

Significant differences in pressure-time integral of obese and normal weight children found in the present study agree with the previous research [21, 32]. Distinctly higher PTI was observed in the 7-14 years old obese children except the toes regions after age of 8 . Both the obese and normal weight participants generated elevated pressure impulses with aging due to the increasing body mass and BMI values. PTI in most plantar regions were found to be significantly different between age groups. Furthermore, significance began to appear at age of 12-14 compared to age of 7-9, even 10 and 11 years old in several regions (M2, M3). It could be concluded that age is a substantial factor considering about plantar pressures, as a potential result of maturation development and appearance of secondary sexual characteristics in the early adolescence.

The relative force-time integral in the present study indicated a disproportional foot loading distribution in obese children, with lower relFTI in toes (T1 and T2-5), medial forefoot (M1 and $\mathrm{M} 2$ ) and heel (HM and $\mathrm{HL}$ ) and higher relFTI in lateral forefoot (M3-5) and midfoot (MF). This kind of imbalance can also be partly found in the study of Mueller et al. [24], who examined the influence of obesity on FTI for children aged 1 to 12 years. Some studies identified highly elevated FTI in the midfoot and the lateral forefoot for obese children [32, 33]. Therefore, in the context of higher plantar loads compared to the normalweight counterparts, load transferences to the lateral forefoot and the midfoot would happen in obese children. However, few significances in relFTI difference of obesity were found after 11 years old. So, obesity would make a difference on plantar pressure distribution and the degree of the impact is partially dependent on age.

It is interesting to find that relFTI values in midfoot of obese children nearly kept unchanged with age, while in midfoot of normal children, relFTI decreased with aging, resulting from the development of longitudinal arch and a natural pressure distribution. One reasonable explanation is that the excess weight laying on the longitudinal arch will cause some collapse, which could also be supported be the larger Al values in the present study. As a result, obesity impedes normal distribution, caused by body development with age, of plantar pressure.

\section{CONCLUSION}

Overall, although obese children have lower foot arches and take larger plantar pressures, the arch development got into maturation before 7 years old for both groups in this study. Foot pressures increased with age and difference showed significance between early-adolescence (12-14 years old) and late-childhood (7-10 years old) stage. Foot loading for obese children would transfer to lateral forefoot and the midfoot compared to the normal weight ones. And the plantar pressure distribution in midfoot of obese children cannot change normally with age, which may be caused by collapse of foot arch. Therefore, special footwear design for obese children is necessary and it would be better to consider about different age stages.

\section{Limitation and Suggestion}

As the time the children have become obese was unknown and inconsistent in this cross-sectional study, further research is needed to examine the long- and short-term influence of obesity during children's development. And due to our limited experiment equipment, our results and discussion could only involve plantar pressure and potential relevance. Further studies combining kinematic data, direct clinical measures, radiographic measures and physical examination would contribute towards a better understanding of the age-related foot function of children with obesity.

\section{Conflict of Interest}

There are no conflicts of interest associated with this research.

\section{Acknowledgement}

The present study obtained financial supportfrom National NaturalScience Foundation of China, grant number: 11502154, as well as Students' Innovation and Entrepreneurship 
Project in Sichuan University. The authors would like to acknowledge all the experimenters for subject recruitment and data collection, and to acknowledge all the participants who made this study possible. We had no writing assistance in this paper.

\section{REFERENCES}

1. Singh, B., Negatu, M.G., Francis, S.L., Janz, K.F., Yack, H.J., Do fitness and fatigue affect gait biomechanics in overweight and obese children?, Gait Posture, 2016, 50, 190-195, https://doi.org/10.1016/j. gaitpost.2016.09.006.

2. Yan, S.H., Zhang, K., Tan, G.Q., Yang, J., Liu, Z.C., Effects of obesity on dynamic plantar pressure distribution in Chinese prepubescent children during walking, Gait Posture, 2013, 37, 1, 37-42, https://doi.org/10.1016/j. gaitpost.2012.05.018.

3. Wills, M., Orthopedic complications of childhood obesity, Pediatr Phys Ther, 2004, 16, 4, 230-235, https://doi.org/10.1097/01. PEP.0000145911.83738.C6.

4. Lerner, Z.F., Board, W.J., Browning, R.C., Effects of obesity on lower extremity muscle function during walking at two speeds, Gait Posture, 2014, 39, 3, 978-984, https://doi. org/10.1016/j.gaitpost.2013.12.020.

5. Da Rocha, E.S., Bratz, D.T.K., Gubert, L.C., de David, A., Carpes, F.P., Obese children experience higher plantar pressure and lower foot sensitivity than non-obese, Clin Biomech, 2014, 29, 7, 822-827, https://doi. org/10.1016/j.clinbiomech.2014.05.006.

6. Mahaffey, R., Morrison, S.C., Bassett, P., Drechsler, W.I., Cramp, M.C., The impact of body fat on three dimensional motion of the paediatric foot during walking, Gait Posture, 2016, 44, 155-160, https://doi.org/10.1016/j. gaitpost.2015.12.009.

7. King, A.C., Challis, J.H., Bartok, C., Costigan, F.A., Newell, K.M., Obesity, mechanical and strength relationships to postural control in adolescence, Gait Posture, 2012, 35, 2, 261-265, https://doi.org/10.1016/j. gaitpost.2011.09.017.

8. Mickle, K.J., Steele, J.R., Munro, B.J., The Feet of Overweight and Obese Young Children: Are They Flat or Fat?, Obesity, 2006, 14, 11, 19491953, https://doi.org/10.1038/oby.2006.227.
9. Villarrasa-Sapiña, I., Serra-Añó, P., PardoIbáñez, A., Gonzalez, L.M., García-Massód, X., Relationship between body composition and vertical ground reaction forces in obese children when walking, Clin Biomech, 2017, 41, 77-81, https://doi.org/10.1016/j. clinbiomech.2016.12.008.

10.Cimolin, V., Capodaglio, P., Cau, N., Galli, M., Pau, M., Patrizi, A., Tringali, G., Sartorio, A., Foot-type analysis and plantar pressure differences between obese and nonobese adolescents during upright standing, Int J Rehabil Res, 2016, 39, 1, 87-91, https://doi. org/10.1097/MRR.0000000000000140.

11.Mesquita, P.R., Neri, S.G.R., Lima, R.M., Carpes, F.P., de David, A.C., Childhood obesity is associated with altered plantar pressure distribution during running, Gait Posture, 2018, 62, 202-205, https://doi.org/10.1016/j. gaitpost.2018.03.025.

12.Yan, S.H., Wang, L., Zhang, K., Effects of different movement modes on plantar pressure distribution patterns in obese and non-obese Chinese children, Gait Posture, 2017, 57, 28-34, https://doi.org/10.1016/j. gaitpost.2017.05.001.

13.Bosch, K., Gerß, J., Rosenbaum, D., Development of healthy children's feet-Nineyear results of a longitudinal investigation of plantar loading patterns, Gait Posture, 2010, 32, 4, 564-571, https://doi.org/10.1016/j. gaitpost.2010.08.003.

14. Bertsch, C., Unger, H., Winkelmann, W., Rosenbaum, D., Evaluation of early walking patterns from plantar pressure distribution measurements. First year results of 42 children, Gait Posture, 2004, 19, 3, 235242, $\quad$ https://doi.org/10.1016/S09666362(03)00064-X.

15.Zeininger, A., Schmitt, D., Jensen, J.L., Shapiro, L.J., Ontogenetic changes in foot strike pattern and calcaneal loading during walking in young children, Gait Posture, 2018, 59, 18-22, https://doi.org/10.1016/j. gaitpost.2017.09.027.

16. Hillman, S.J., Stansfield, B.W., Richardson, A.M., Robb, J.E., Development of temporal and distance parameters of gait in normal children, Gait Posture, 2009, 29, 1, 81-85, https://doi. org/10.1016/j.gaitpost.2008.06.012.

17.Müller, J., Müller, S., Baur, H., Mayer, F., Intraindividual gait speed variability in healthy 
children aged 1-15 years, Gait Posture, 2013, 38, 4, 631-636, https://doi.org/10.1016/j. gaitpost.2013.02.011.

18.Stavlas, P., Grivas T.B., Michas, C., Vasiliadis, E., Polyzois, V., The Evolution of Foot Morphology in Children Between 6 and 17 Years of Age: A Cross-Sectional Study Based on Footprints in a Mediterranean Population, J Foot Ankle Surg, 2005, 44, 6, 424-428, https://doi.org/10.1053/j.jfas.2005.07.023.

19.McKay, M.J., Baldwin, J.N., Ferreira, P., Simic, M., Vanicek, N., Wojciechowski, E., Mudge, A., Burns, J., Spatiotemporal and plantar pressure patterns of 1000 healthy individuals aged 3-101 years, Gait Posture, 2017, 58, 78-87, https://doi.org/10.1016/j. gaitpost.2017.07.004.

20.Samson, W., Dohin, B., Desroches, G., Chaverot, J.L., Dumas, R., Cheze, L., Foot mechanics during the first six years of independent walking, J Biomech, 2011, 44, 7, 1321-1327, https://doi.org/10.1016/j. jbiomech.2011.01.007.

21.Bosch, K., Gerss, J., Rosenbaum, D., Preliminary normative values for foot loading parameters of the developing child, Gait Posture, 2007, 26, 2, 238-247, https://doi. org/10.1016/j.gaitpost.2006.09.014.

22. Waseda, A., Suda, Y., Inokuchi, S., Nishiwaki, Y., Toyama, Y., Standard growth of the foot arch in childhood and adolescence-Derived from the measurement results of 10,155 children, J Foot Ankle Surg, 2014, 20, 3, 208-214, https://doi.org/10.1016/j.fas.2014.04.007.

23.Müller, S., Carlsohn, A., Müller, J., Baur, H., Mayer, F., Static and dynamic foot characteristics in children aged 1-13 years: A cross-sectional study, Gait Posture, 2012, 35, 3, 389-394, https://doi.org/10.1016/j. gaitpost.2011.10.357.

24.Müller, S., Carlsohn, A., Müller, J., Baur, H., Mayer, F., Influence of Obesity on Foot Loading Characteristics in Gait for Children Aged 1 to 12 Years, Plos One, 2016, 11, 2, e149924, https://doi.org/10.1371/journal. pone.0149924.

25. Krebs, N.F., Himes, J.H., Jacobson, D., Nicklas, T.A., Guilday, P., Styne, D., Assessment of child and adolescent overweight and obesity, Pediatrics, 2007, 120 Suppl 4, S193-S228, https://doi.org/10.1542/peds.2007-2329D.
26.Demirbüken, O., Özgül, B., Timurtaş, E., Yurdalan, S.U., Çekin, M.D., Polat, M.G., Gender and age impact on plantar pressure distribution in early adolescence, Acta Orthop Traumato, 2019, 53, 3, 215-220, https://doi. org/10.1016/j.aott.2019.01.006.

27.Group Of China Obesity Task Force, Ji C., Body mass index reference norm for screening overweight and obesity in Chinese children and adolescents, Chinese Journal of Epidemiology, 2004, 25, 02, 10-15.

28. Menz, H.B., Two feet, or one person? Problems associated with statistical analysis of paired data in foot and ankle medicine, The Foot, 2004, 14, 1, 2-5, https://doi.org/10.1016/ S0958-2592(03)00047-6.

29. Cavanagh, P.R., Rodgers, M.M., The Arch Index: a useful measure form footprints, J Biomech, 1987, 20, 5, 547-551, https://doi. org/10.1016/0021-9290(87)90255-7.

30.Zhao, Y., Liu, Z., Zhang, X., Yang, L., Chen, W., Analysis of characteristics in China classic dancers' gait pattern, Leather and Footwear Journal, 2018, 18, 2, 131-138, https://doi. org/10.24264/Ifj.18.2.8.

31.Strutzenberger, G., Richter, A., Schneider, M., Mündermann, A., Schwameder, H., Effects of obesity on the biomechanics of stair-walking in children, Gait Posture, 2011, 34, 1, 119-125, https://doi.org/10.1016/j. gaitpost.2011.03.025.

32.Cousins, S.D., Morrison, S.C., Drechsler, W.I., Foot loading patterns in normal weight, overweight and obese children aged 7 to 11 years, J Foot Ankle Res, 2013, 6, 1, 36, https:// doi.org/10.1186/1757-1146-6-36.

33.Yan, S., Zhang, L., Li, X., Li, R., Zhou, N., Cai, X., Yang, L., Foot Pressure Characteristics of Chinese Overweight and Obese Children during Gait, Leather and Footwear Journal, 2016, 16, 3, 237-252, https://doi. org/10.24264/Ifj.16.3.5.

(C) 2020 by the author(s). Published by INCDTPICPI, Bucharest, RO. This is an open access article distributed under the terms and conditions of the Creative Commons Attribution license (http:// creativecommons.org/licenses/by/4.0/). 